УДК. 378. 012

http://ORCID: 0000-0001-8377-4076

DOI: $10.34142 / 23128046.2021 .51 .07$

Дзін Лань

\title{
ОСОБЛИВОСТІ ФОРМУВАННЯ ОРГАНІЗАЦІЙНОЇ КУЛЬТУРИ У КИТӒ̈
}

Актуальність дослідження зумовлена недостатнім вивченням питання особливостей формування організаиійної культури в Китайській Народній Республічі як країні, яка на сьогодні має одні із вищих показників розвитку економіки та виробництва. Метою статті стало виявлення особливостей формування організаційної культури в Китайській Народній Республіиі (КНР).

Установлено, щу, починаючи з 1978 року, КНР активно впроваджувала реформи, спрямовані на відкритість та розвиток економіки країни. Важливе місие серед иих реформ було призначено саме освіті, научі та культурі. Поняття «організаційна культура» набуло популярності на початок 1980-х рр., проте і досі не існує його єдиного загальноприйнятого визначення.

Під сутністю поняття «організачійна культура» у КНР розуміють поведінку як норму відносин на виробничтві, котра базується на неприхованих правилах спілкування, які підпорядковані меті компанії, і виступає важливим чинником економічного розвитку виробництва.

Серед функиій організаційної культури фахівиі визначають: планувальну, згуртування колективу; мотивачійну; контролюючу; функцію впливу; інтегративні функиії; функцію гармонії; управлінську.

Серед особливостей формування організаиійної культури у КНР визначено: позитивне ставлення до культури та мистецтва, котрі спрямовані на розвиток сфери духу, емоиій, чуйності та унікальності особистості; розумне управління компаніями у КНР, яке передбачає прояв таких якостей, як: чуйність, творчість, професійна етика та емоційність; регулювання взаємовідносин в управлінні перш за все моральними нормами, які іноді стають вище за закон; домінування політичної культури в суспільному та культурному житті; формування організаційної культури в процесі постійного реформування; розвиток особистості та суспільства через інновачії; вивчення моделей управління зарубіжних краӥн та їх упровадження з урахуванням національних особливостей; трунтування організаџійної культури на відповідних компетентностях, наполегливій праці; розробка системи мотивів і стимулів 3 урахуванням національних традииій країни.

Ключові слова: організаційна культура, особливості організаційної культури, КНР, функиії.

Jin Lang. Features formation of organizational culture in China. The relevance of the study is due to insufficient study of the peculiarities of the formation 
of organizational culture in the People's Republic of China as a country that has today one of the highest indicators of economic development and production. The aim of the article was to identify the features of the formation of organizational culture in the People's Republic of China (PRC).

It is established that since 1978, China has been actively implementing reforms aimed at openness and economic development of the country, an important place among these reforms was assigned to education, science and culture. The concept of "organizational culture" gained popularity in the early 1980's, but there is still no single common definition.

The essence of the concept of "organizational culture" in China is behavior as a norm of relations in production, which is based on undisguised rules of conduct that are subject to the goals of the company, and is an important factor in economic development.

Among the functions of organizational culture are defined: planning, team cohesion; motivational, controlling; influence function; integrative function; harmony function; management.

Among the features of the formation of organizational culture in China are: attitude to culture and art aimed at developing the sphere of spirit, emotions, sensitivity and uniqueness of the individual; corporate governance in China involves sensitivity, creativity and emotionality.

Relationships in management are governed primarily by moral norms that sometimes become higher than the law; professional ethics; the dominance of political culture in social and cultural life; formation of organizational culture in constant reform; development through innovation; taking into account the management models of foreign countries, but their implementation taking into account national characteristics; based on competencies, hard work, development of a system of motives and incentives taking into account the national traditions of the country.

Key words: organizational culture, features of organizational culture, China, function.

Вступ. Сьогодні Китайська Народна Республіка - одна із країн, яка займає провідну позицію щодо швидкості розвитку економіки та виробництва. Саме тому багато науковців із різних країн світу звертають увагу на дослідження резервів даної країни, які призвели до таких швидких темпів розвитку сфери політики, економіки, політології, соціології та культурології даної країни. Ден Сяопін відзначав, що великою помилкою для становлення та розвитку КНР став брак спеціалістів із вищою освітою (Deng Xiaoping, 1993). Починаючи 31978 року, КНР активно впроваджувала реформи, спрямовані на відкритість та розвиток економіки країни, важливе місце серед цих реформ було призначено саме освіті, науці та культурі (Deng Xiaoping, 1993).

Проведене дослідження дає змогу стверджувати, що організаційна культура в КНР зароджувалась у межах корпоративної культури та почала своє існування 3 виникнення перших підприємств. Проте, організаційна культура має власні особливості, котрі обумовлені культурою її формування в межах КНР. Отже, 
вважаємо за необхідність на основі аналізу філософської, психологопедагогічної літератури визначити особливості формування організаційної культури в Китаї.

Сьогодні проблема формування та розвитку організаційної культури $є$ предметом уваги багатьох вітчизняних учених - Г. Кравченко, О. Драган, 3. Шершньова та інших. Наукові розвідки зазначених фахівців пов'язані 3 аналізом організаційної культури, присвячені визначенню сутності, структури, функцій даної культури. Проте, ще недостатньо приділено уваги науковцями вивченню саме особливостей формування організаційної культури у різних країнах світу, наприклад, КНР.

Мета та завдання. Мета cmammi полягає у визначенні особливостей формування організаційної культури в КНР.

Методи дослідження. Одним із головних методів у дослідженні став кроскультурний, що дозволив нам включити до кола об'єктів, які вивчаються, норми, звички, ритуали і звичаї повсякденного життя китайців. У ході дослідження використовувались також китайські тексти та їх переклад, що обумовило застосування герменевтики як методу інтерпретації і розуміння текстів.

Результати. Проведений науковий аналіз дає змогу стверджувати, що організаційна культура, незважаючи на те, що зародилась ще в давнину, є досить молодим напрямом дослідження. 3 цього приводу Г. Хофстеде зазначав, що як поняття «організаційна культура» набула популярності лише на початку 1980х pp. Загального визначення даного поняття не існує i досі, проте більшість науковців визначають такі характерні риси цього понятті, як: цілісність, історична обумовленість, створеність суспільством, ненав'язливість, не змінність поняття, що характерно для кожної організації (Hofstede, 2002).

Згідно з офіційним китайським словником «Новий китайський словник» запропоновано декілька різних визначень поняття «культура», як-от: 1) сукупність матеріальних i духовних багатств, створених людством у процесі свого історичного розвитку і соціальної практики; 2) форма зміни середовища людиною, іiі здатність адаптуватися до цих змін, спосіб виживання людства, сукупне вираження морального обличчя народу (Lu Limei \& Wang Qunhui, 2012). Згідно до другого розуміння терміну «культура» у КНР, він застосовується тільки до духовної спадщини: науки, освіти, літератури, мови, мистецтва та ін. (Lu Limei \& Wang Qunhui, 2012 ).

Так, у КНР сутністю організаційної культури виступає поведінка як норма відносин на виробництві, котра займає більш важливу позицію для керівництва ніж менеджмент у компанії. Організаційна культура базується на неприхованих правилах поведінки, які підпорядковані меті компанії, і стає важливим чинником економічного розвитку виробництва в цілому. В основі організаційної культури китайські вчені - Сюй Мэн, Ву Шэньи, Се Сянйин - надають перевагу цінностям (Xu Meng, 2014; Wu Shenyi \& Xie Xiangyin, 2012 ), які в свою чергу визначаються такою рисою, як чесність: чесніть за контрактом, чесність на основі асиметричності інформації, чесність щодо урахування інтересів двох сторін. 
На сьогодні дослідники організаційної культури КНР (Лі Івен, Ши Фенбо) визначають наступні ii характеристики: спрямованість на людину; систематичний та колективний характер; відкритість та інклюзивність; стійкість та довготривалість розвитку; усвідомлення розумом та серцем; унікальність та особливість (Lee Ewen \& Shi Fenbo, 2012 ).

Серед функцій організаційної культури визначають: планувальну спрямовує напрям розвитку підприємства та його взаємостосунки з оточуючим світом; згуртування колективу; мотиваційну - передбачає індивідуальні стимули, які переростають у групові; контролюючу - включає контроль над реальністю; функцію впливу - поширення впливу культури на інших; інтегративні функції - поєднання ресурсів та ефективності праці; функцію гармонії - встановлення позитивних міжособистісних стосунків у колективі; управлінську - управління колективом (Lee Ewen \& Shi Fenbo, 2012).

На сьогодні організаційна культура КНР розглядається в таких економічних аспектах, як: організація найкращої співпраці між компанією та ії працівниками та можливість заощадження трансакційних витрат завдяки організаційній культурі та командному духу іiї працівників.

3 метою реалізації найкращої співпраці між компанією та їі працівниками $\mathrm{X}$. Робенсон розробив теорію ігор «Дилеми в'язня». Дана гра спрямована на аналіз продуктивності праці робітників. При проведенні гри робітники ставали перед вирішення проблеми обрання пріоритетів: інтереси компанії, або власні особистісні інтереси. У свою чергу керівники ставали перед вибором концепції розвитку компанії з таких позицій: 1 . забезпечити працівників кращими умовами праці та заробітною платнею відповідно до прибутку компанії; 2. мінімізувати витрати завдяки економії на облаштуванню умов праці працівників та збільшити прибуток компанії й активізувати діяльність її працівників. У процесі гри між підприємством та працівниками виникали два типи поведінки - змагальна та кооперативна. У результаті гри, зазвичай, керівництво та працівники робили такий висновок, що перші - знижують продуктивність праці, а другі - iї збільшують.

X. Робенсон уважав, що на основі таких тренінгів можливо сформувати звички толерантної співпраці, що в свою чергу позитивно впливає на розвиток організаційної культури компанії в цілому. I саме за допомогою сформованих неринкових звичок працівників, до яких він відносив чесність, довіру, репутацію, можливо усунути або зменшити кількість конфліктів на підприємстві, збільшити продуктивність праці, об'єднати в колектив співробітників, що сприятиме формуванню організаційної культури та досягненню балансу в середині підприємства.

Другу ідею - можливості заощадження трансакційних витрат завдяки організаційній культурі та командному духу співпрацівників - доводили такі вчені як А. Сен, А. Алчіан та інші (А. Saint, 1972; A. Alcian 1984 ). Зокрема, А. Сен - лауреат нобелівської премії з економіки 1998 р. - зазначав, що суспільство, засноване на особистісних інтересах та відсутності сформованості організаційних цінностей, не $є$ привабливим у культурному сенсі. Таке 
суспільство економічно неефективне, оскільки вузькі особистісні інтереси не підуть на користь благополуччя.

А. Алчіан вважає, що організаційна культура - це вагома складова управлінської системи підприємства. Організаційна культура формується несвідомо в процесі спілкування між співробітниками, вона має власний життєвий цикл, передається від покоління до покоління і базується на ціннісних переконаннях, етичних нормах, моральних концепціях та звичках. Організаційна культура лежить в основі кооперативного виробництва, яке є більш економічно ефективним, ніж продукція окремих суб'єктів.

Важливою складовою організаційної культури в КНР виступає професійна етика. Згідно до якої працівники мають бути працелюбними, відданими професійній праці, життєрадісними, ретельно виконуючими свої обов'язки; чесними, надійними, дисциплінованими, поважливими до законів компанії, соціально відповідальними.

Однією з особливостей організаційної культури у КНР виступає загальне ставлення до культури. Як відомо, західна культура базується на науці, праві, релігії, характеризується точністю, раціональністю та чітким плануванням. Данні положення пронизують всю галузь теорії менеджменту західних країн. Наприклад, наукова теорія менеджменту Тейлора, виступає за стандартизацію кожного руху людей із метою підвищення ефективності їх роботи. Зокрема, управління точністю в американських компаніях відображається в таких аспектах: незалежно від масштабів компанії, вона чітко визначає корпоративні цілі, політику, бюджет, плани. Розробляються чіткі стандарти звітності, оцінки результатів; оприлюднюється будь-яка інформація про ділову діяльність компанії; всі данні, які використовуються в компанії є максимально точними. Будь-яка інформація, яка надходить до компанії проходить ретельну перевірку та аналізується для того, щоб кожне рішення мало міцну наукову основу.

В основі організаційної культури лежить перш за все закон. Так, порушення службового обов'язку є основою для проведення службового розслідування в результаті якого особистість - порушник буде суворо покарана. Проте, з метою забезпечення достовірності даних, сам процес розслідування може затягнутися.

Східна ж культура, на відміну від західної, зосереджується на мистецтві, а мистецтво, у свою чергу, концентрує увагу на оцінці зовнішньої форми. Мистецтво підкреслює сферу, дух, емоції, чуйність та унікальність особистості.

Вся організаційна культура в КНР вимагає чуйність, творчість та емоційність навіть в управленні компанією. Традиційні морально-етичні погляди суттєво впливають на думки та поведінку людей. Етика і моральне виховання в Стародавньому Китаї базувалося на використанні мистецьких методів, що формує модель поведінки, спрямовану на співпрацю, співіснування, взаємодопомогу і не передбачає регулювання взаємовідносин законами права. Особливістю співпрацівників КНР є ставлення до закону як до примусу людини до певної поведінки. 3 огляду на це, працівники КНР надають великого значення етичному вихованню та побудові стосунків, котрі засновані на довірі та повазі один до одного. 
Творчий підхід в управлінні бізнесом відображено всередині культури підприємства. Весь процес прийняття рішення від аналізу, формулювання мети до практичного виконання дій, усі взаємостосунки між керівництвом та співробітниками базуються на прихильності та довірі. Проте, такі відносини мають і негативний характер. Відносини, побудовані на довірі, приводять до відсутності контрактів між компанією та її працівникам, що, в свою чергу, веде до не визначення обов'язків кожної із сторін.

Творче мислення та недостатня чіткість в управлінні компаніями призводить до відсутності довготривалих планів розвитку компаній, що призводить до браку фінансів.

Отже, організаційна культури співробітників КНР базується на моральному вихованні, яке регулює поведінку людини в суспільстві.

Піклування один про одного, підтримка один одного сприяють розвитку міжособистісних відносин у колективі співпрацівників КНР. Як уже було зазначено, в КНР прийнято таке положення, яке не дозволяє ігнорувати етику та мораль заради верховенства закону.

Характеризуючи особливості поняття «розвиток» у західній культурі та культурі Китаю, слід відмітити, що вони мають зовсім протилежні погляди. Зокрема, китайські мудреці так характеризують розвиток: західна культура шукає розвиток в тиші, в той час як культура КНР шукає спокій у розвитку. Під поняттям «прояв розвитку в тиші» мається на увазі прогрес, новаторство, змагання, створення конкуренції, що часто приводить до розвитку через негатив. Політика Китаю зосередилася на вивченні та опануванні позитивного досвіду інших, використанні та підтримці найкращого. Пошук новацій у західній культури призводить до постійних перевірок, удосконалень, що негативно впливає на працівників компаній.

Слід зазначити що КНР є соціалістичною країною, тому політична культура завжди домінує в суспільному та культурному житті.

Ідеологія партії впливає на всі сфери економіки та політики, і накладає свій відбиток на розвиток бізнесу й управління компаніями, а, отже, має великий вплив на формування організаційної культури в КНР.

Наступною характеристикою та особливістю формування організаційної культури є іiі розвиток в постійному реформуванні економічних та соціальних сфер. Глобальні зміни в сфері економіки призвели до суттєвих змін у мисленні та сприйнятті світу. Враховуючи це, організаційна культура Китаю змінилася із замкнутого мислення до вільного, відкритого новаторства.

3 відкриттям Китаю для світу змінювались і орієнтири розвитку підприємств, на ринок прийшли іноземні компанії, які принесли з собою нову культуру, цінності, що сприяло реформуванню інноваційної культури КНР.

3'явились праці науковців, присвячені дослідженню організаційної культури, розвитку людських ресурсів та менеджменту, які засновувались на ідеях західної культури корпоративного управління. 
Незважаючи на бурхливий розвиток економіки та виробництва, у КНР підтримується історична ідея - спрямованість на створення єдиного мислення, єдиного командного духу, який націлений на інноваційність та на особистість.

Інновації виступають невід'ємною ознакою всього культурного розвитку. Передова культура невіддільна від інновацій.

Лю Тао (Liu Tao, 2006) відзначає, що, з одного боку, китайці повинні вчитися на корисному досвіді західної корпоративної культури та успадковувати історичні й культурні традиції, а, з іншого, - адаптуватися до мінливої нової ситуації та створити власну соціалістичну організаційну культуру з сучасною свідомістю і сучасним змістом.

Отже, організаційна культура КНР має будуватися на моделі управління 3 урахуванням особливостей розвитку Китаю. Нові сучасні компанії КНР мають підкреслювати свою індивідуальність та культуру.

Головними принципами такої організаційної культури в КНР є: індивідуальність, єдність соціальної та організаційної культур; наявність у компаніях стратегії розвитку організаційної культури; персоналізована діяльність підприємств, цінності та стиль управління; відсутність стандартної і єдиної моделі організаційної культури; наявність унікальної організаційної культури.

Організаційна культура у КНР грунтується на певних компетентностях, наполегливій праці, розробці системи стимулів, а саме: достойна заробітна плата та соціальне забезпечення підлеглих; спрямованість культури на розвиток талантів у кожного співробітника організації; відкритість і толерантність; інноваційність, чесна конкуренція, професіоналізм (китайські компанії повинні прагнути зміцнити розвиток професіоналізму співробітників і навчити їх тому, як це робити).

Побудова організаційної культури у КНР має грунтуватися i на національних традиціях країни, відображати національні особливості та формувати культуру самобутньої особистості.

Обговорення. Проведене дослідження підтверджує висновки вчених про те, що формування організаційної культури в КНР після реформ 1978 року відбувалось згідно до нового підходу, у відповідності з яким персонал розглядається не просто як сукупність працівників, а як об'єкт управління, що вимагає обліку соціальних характеристик, професійних знань і особистісних здібностей, трудової мотивації, здатності до оптимальних міжособистісних відносин.

Ставлення до кадрів, до людських ресурсів характеризує ставлення компанії до працівників, до розуміння їх ролі в загальному успіху, а також відображає особливості стилю управління, що переважає в трудовій організації. Китайська організаційна культура характеризується наступними показниками: тісна інтеграція політики та економіки; активний розвиток міжнародних підприємств; наявність соціальних цілей в економіці КНР; домінування політичної культури.

Висновки. Отже, під поняттям «організаційна культура» у КНР розуміють поведінку як норму відносин на виробництві, котра базується на неприхованих 
правилах спілкування, які підпорядковані меті компанії і виступають важливим чинником економічного розвитку виробництва.

До провідних принципів формування організаційної культури у КНР належать: індивідуальність; єдність соціальної та організаційної культури; наявність у компаніях стратегії розвитку організаційної культури; персоналізована діяльність, цінності та стиль управління для розвитку i вдосконалення власного підприємства; відсутність стандартної та єдиної моделі організаційної культури; наявність унікальної організаційної культури.

Серед функцій організаційної культури науковці визначають: планувальну; згуртування колективу; мотиваційну; контролюючу; функцію впливу; інтегративні функції; функцію гармонії; управлінську.

Фахівці також визначають наступні характеристики організаційної культури: спрямованість на людину; систематичний та колективний характер; відкритість та інклюзивність; стійкість та довготривалість розвитку; усвідомлення розумом та серцем; унікальність та особливість; побудова на ціннісних переконаннях, етичних нормах, моральних концепціях та звичках.

Серед особливостей формування організаційної культури у КНР визначаємо:

- ставлення до культури та мистецтва як до галузей, котрі спрямовані на розвиток духу, емоцій, чуйності та унікальності особистості;

- побудова управління компаніями у КНР на засадах чуйності, творчості, емоційності, моральних норм, які іноді стають вище за закон;

- виконання положень професійної етика згідно до якої працівники мають бути працелюбними, відданими професійній праці, життєрадісними, ретельно виконувати свої обов'язки, бути чесними, надійними, дисциплінованими, поважати закони компанії, служити народу, соціально відповідальними.

- домінування політичної культури у суспільному та культурному житті країни;

- формування організаційної культури в постійному реформуванні економічних та соціальних сфер життя;

- розвиток організаційної культури відбувається завдяки постійним інноваціям;

- урахування моделі управління зарубіжних країн, упровадження іноземних новації з урахуванням національних особливостей Китаю;

- грунтування організаційної культури на компетентностях, наполегливій праці, розробці системи мотивів і стимулів з урахуванням національних традицій країни.

\section{ЛІТЕРАТУРА:}

Драган О. І. Організаційна культура підприємства (організації): теоретичний підхід. Економіка і менеджмент культури. 2012. № 1-2. С. 25-28.

Кравченко Г. Ю. Адаптивне управління розвитком інститутів післядипломної педагогічної освіти в Україні. Монографія. Х., Смугаста типографія», 2015. 300 с.

Кравченко Г. Ю., Дзінь Лань Організаційна культура в адміністративному управлінні закладами вищої освіти Китаю. Наукові записки Бердянського державного університету. Серія: Педагогічні науки. Вип. 2. Бердянськ, 2020. С. 78-87. 
Организационная культура Хофстеде Г. Управление человеческими ресурсами. под ред. М. Пула, М. Уорнера. СПб., Питер, 2002. С. 313-338.

Шершньова 3. С. Стратегічне управління: навч. посіб. К.: КНЕУ, 1999. С. 66-84.

邓小平文选 (第3 卷). 北京: 人民出版社, 1993.418页.

路丽梅，王群慧. 新编汉语辞海. 光明日报出版, 2012年. 1831页.

许萌. 企业文化落地与突破. 北京：中国财富出版社 2014. 240页.

吴声怡, 谢向英. 企业文化新教程. 上海：上海大学出版社 2012.03. 337页.

王成荣. 企业文化职工读本. 北京 : 中国工人出版社 2012.04. 211页.

中国式企业文化塑造的战略思考专业名称: 高级管理人员工商管理硕士 申请人姓名: 李毅

文 导师姓名及职称：石风波副教授 论文答辩主席：万委员：答辩日期：2. $\|$ 年 $2 \mathrm{C}$ B2,L-El 90页.

团队生产理论回顾

Режим

доступу:

https://wiki.mbalib.com/wiki/\%22\%E5\%9B\%A2\%E9\%98\%9F\%E7\%94\%9F\%E4\%BA\%A

7\%22\%E7\%9A\%84\%E7\%90\%86\%E8\%AE\%BA\#.E5.8F.82.E8.80.83.E6.96.87.E7.8C.AE

\section{REFERENCES:}

Drahan, O. I. (2012) Orhanizatsiina kultura pidpryemstva (orhanizatsii): teoretychnyi pidkhid. [Organizational culture of the enterprise (organization): a theoretical approach]. Ekonomika i menedzhment kultury. (1-2), 25-28 (in Ukranian).

Kravchenko, H. Iu. (2015) Adaptyvne upravlinnia rozvytkom instytutiv pisliadyplomnoi pedahohichnoi osvity $\mathrm{v}$ Ukraini. [Adaptive management of development of institutes of postgraduate pedagogical education in Ukraine]. Monohrafiia. Kh., Smuhasta typohrafiia» (in Ukranian).

Kravchenko, H. Iu., Dzin Lan (2020) Orhanizatsiina kultura v administratyvnomu upravlinni zakladamy vyshchoi osvity Kytayu. [Organizational culture in the administrative management of higher education institutions in China]. Naukovi zapysky Berdianskoho derzhavnoho universytetu. (Seriia: Pedahohichni nauky), Berdiansk. (2), 78-87 (in Ukranian).

Pul, M. (Ed) (2002) Organizacionnaya kul'tura Hofstede G. [Organizational culture Hofstede G.]. Upravlenie chelovecheskimi resursami. M. Uornera. SPb., Pyter, 313-338 (in Russian).

Shershnova, Z. Ye. (1999) Stratehichne upravlinnia. [Strategic management]: navch. posib. K.: KNEU, 66-84 (in Ukranian).

邓小平文选 (第3 卷). (1993) 北京: 人民出版社, 418页. (in China)

路丽梅，王群慧. (2012) 新编汉语辞海. 光明日报出版, 年. 1831页. (in China)

许萌. 企业文化落地与突破. (2014) 北京 : 中国财富出版社 240页. (in China)

吴声怡, 谢向英. (2012) 企业文化新教程. 上海：上海大学出版社 337页. (in China)

王成荣. (2012) 企业文化职工读本. 北京 : 中国工人出版社 211页.

中国式企业文化塑造的战略思考 (2014) 专业名称: 高级管理人员工商管理硕士 申请人姓名 : 李毅文 导师姓名及职称：石风波副教授 论文答辩主席：万委员：答辩日期：2. ॥年2 C B2,L-El 90页. (in China)

团队生产理论回顾

URL:

https://wiki.mbalib.com/wiki/\%22\%E5\%9B\%A2\%E9\%98\%9F\%E7\%94\%9F\%E4\%BA\% 


\section{Інформація про автора:}

Дзін Лань: http:// ORCID: 0000-0001-83774076, здобувач третього (освітньонаукового) рівня вищої освіти, Харківський Національний економічний університет ім. Семена Кузнеця, пр. Науки, 9-а, Харків, Україна, 61166

e-mail:post@hneu.edu.ua

\section{Information about the author:}

Jin Lang: http:// ORCID: 0000-0001-83774076, Ph.d. candidate, S. Kuznets Kharkiv National University Economy, Nauky prospectus, 9-a, Kharkiv, Ukraine 61166

Цитуйте цю статтю як: Дзін Лань Особливості формування організаційної культури у Китаї. -Теорія та методика навчання та виховання. 2021. № 51. С. 67-76. DOI: $10.34142 / 23128046.2021 .51 .07$

Дата надходження статті до редакції: 22.09.2021

Стаття прийнята до друку: 07.10.2021 